\title{
The Measurement Of Performance Using The Balanced Score Card In Islamic Banking
}

\author{
Tri Wahyuni ${ }^{1}$, Suwignyo Widagdo ${ }^{2}$, Hamzah Fansuri Yusuf ${ }^{3}$ \\ Student STIE Mandala Jember ${ }^{1}$, Lecturer, STIE Mandala Jember ${ }^{2,3}$ \\ Email: suwignyo@stie-mandala.ac.id ${ }^{2}$
}

\begin{abstract}
This study aimed to analyze the extent to which performance of the PT. BPR Sinar Artha Wuluhan when measure $d$ using the four perspectives of the Balanced Scorecard. The research was conducted on the company's performance in 2013-2014. The data used are primary data obtained from interviews with the resource persons and distributing questionnaires to the respondents as many as 130 respondents, ie 95 respondents and 35 respondents. This study also used secondary data obtained from various sources such as the internet, books, journals, theses, and others associated with this research. Data processing method using test data quality, the data validity test and reliability test data to test the questionnaire with the help of analysis tools SPSS version 20. The data processing also uses four perspectives of the Balanced Scorecard, the financial perspective using ROA, ROE and NPM. Customers use the perspective of customer acquisition, customer retention and customer satisfaction. Internal business perspective using indicators of innovation and operations. Learning and Growth perspective using a level employee productivity, employee retention and employee satisfaction. The results showed overall scores obtained by the performance of the company amounted to $46,9 \%$ who expressed the company's performance is not good. However, there is increasing from year to year has increased its performance is quite good.
\end{abstract}

Keywords: Performance Measurement, Balanced Score Card

\section{INTRODUCTION}

The current performance measurement carried out by the company aims to determine the extent of the development and success that has occurred in the company. Many performance measurements carried out in companies only focus on the financial aspects, without paying 
attention to other aspects. The Balanced Scorecard measurement system will be able to help managers to see the business in four perspectives, namely finance, customers, internal business processes, and learning and growth. The concept of measuring the Balanced Scorecard is associated with four categories, namely financial measures, customer sizes, business process measures, and human resource measures.

Sri Wahyuni (2011) conducted research with the results obtained that by using a balanced scorecard which includes financial perspective, customer perspective, internal organization perspective, and learning and growth perspective at PT. Semen Bosowa Maros can be said to be quite good. Wayan Adhitya Nugroho (2013), the results of the study that using the balanced scorecard concept show that WIKA's financial performance is better than the previous year, but overall it can be considered good. Novella Aurora (2010) states that by using the Balanced Scorecard there are several variations in the achievement of results. The growth and learning perspectives are still considered lacking, while the other 3 perspectives are considered good enough, so the Balanced Scorecard is suitable to be applied to the Tugurejo Regional General Hospital Semarang. Here are some theories that underlie the research: The Balanced Scorecard is a measuring tool created by Robert S. Kaplan and David P. Norton as a company performance measurement tool for modern business environments. At first the Balanced Scorecard was created to overcome the problem of weakness in measuring performance management which is too focused on finances, then the Balanced Scorecard has developed in its implementation in the company.

Starting in mid-1993, P. Norton's consulting firm, Renaissance Resolution, INC. , implementing the Balanced Scorecard in various client companies. Since then, the Balanced Scorecard has not only been used as a performance measurement system but has developed as a strategic management system.

Rangkuti (2011: 205) states that senior managers must pay attention to the four perspectives that make up the Balanced Scorecard, namely: Financial Perspective, How is the company viewed by shareholders? Customer Perspective, How do customers understand the company's products and services? Internal Business Process Perspective, what value drivers can drive business processes so that they can be featured? Learning and Growth Perspective, Can the company produce innovation, change and improvement?. 


\section{RESEARCH METHODS}

\section{Object of research}

The object of this research is PT. BPR Sinar Wuluhan Artha which is located at Jalan Pahlawan No.167 Wuluhan.

\section{Population and Sample}

The population in this study were all employees of 53 people and customers as many as 1.317 PT. BPR Sinar Wuluhan Artha in 2014. Sampling was done using the Slovin formula, which is a sample of 35 employees were obtained as respondents to fill out a questionnaire from a learning and growth perspective and a sample of 95 customers as respondents to fill out a questionnaire from a customer perspective.

\section{Operational Definition of Variables}

1) Financial Perspective

Describe the long-term goals, high return on investment of each business unit. From this financial perspective, measurements are made using ratio analysis, such as Return On Assets (ROA), Return On Equity (ROE) and Net Profit Margin (NPM).

\section{2) Customer Perspective}

The market segment is a source that will become a component of the company's financial goals income. From the customer perspective, measurement will be carried out using several indicators, such as customer retention rate, customer acquisition rate and customer satisfaction level.

3) Internal Business Process Perspective

In this perspective, the measurement is carried out with the innovation indicator which is seen from how many new innovations there are in the company compared to the target the company wants to achieve, the operation process and after-sales service / good post-service relationship with customers.

\section{4) Learning and Growth Perspective}

This learning and growth perspective is more focused on employee performance, so that measurement is done by measuring employee productivity, employee retention and employee turnover, as well as measuring the level of employee satisfaction. 
5. Data Analysis Methods

1) Test data quality in this study using:

a) Data Validity Test

b) Data Reliability Test

2) Test data analysis in this study using:

a) Financial Perspective

- ROA (Return On Asset)

- ROE (Return On Equity)

- NPM (Net Profit Margin)

b) Customer Perspective

- Customer Acquisition Rate

- Customer Retention Rate

- Customer Satisfaction Level c) Internal Business Process Perspective

- Innovation process

- Operation process

d) Learning and Growth Perspective

- Employee Productivity

- Employee Retention

- Employee Satisfaction

\section{RESULT AND DISCUSSION}

The profile of respondents can be seen that the number of customers is 95 people and employees are 35 people. With a total of 130 people all of whom meet the requirements for processing.

Table 1.Customer Reliability Test Results

\begin{tabular}{|c|c|c|}
\hline $\begin{array}{l}\text { Cronbach's } \\
\text { Alpha }\end{array}$ & $\begin{array}{c}\text { Cronbach's Alpha Based on } \\
\text { Standardized Items }\end{array}$ & $\mathrm{N}$ of Items \\
\hline ,702 & ,727 & 9 \\
\hline
\end{tabular}


A construct or variable is said to be reliable if the value of Cronbacch Alpha $(\alpha)>0.60$. Whereas in the SPSS 20 test, for the variable reliability test, it was known that the reliability value of Cronbach's Alpha was 0.702> 0.60. This proves that the questionnaire instrument in the study is reliable and researchable.

Table 2. Customer Validity Test Results

Item-Total Statistics

\begin{tabular}{|l|r|r|r|r|r|}
\hline & \multicolumn{1}{|l|}{$\begin{array}{l}\text { Scale Mean if } \\
\text { Item Deleted }\end{array}$} & $\begin{array}{c}\text { Scale Variance if } \\
\text { Item Deleted }\end{array}$ & $\begin{array}{c}\text { Corrected Item- } \\
\text { Total Correlation }\end{array}$ & $\begin{array}{c}\text { Squared Multiple } \\
\text { Correlation }\end{array}$ & $\begin{array}{c}\text { Cronbach's Alpha if } \\
\text { Item Deleted }\end{array}$ \\
\hline kp1 & 32,40 & 2,711 &, 316 &, 147 &, 688 \\
kp2 & 32,48 & 2,550 &, 404 &, 251 &, 671 \\
kp3 & 32,46 & 2,656 &, 460 &, 394 &, 662 \\
kp4 & 32,32 & 2,857 &, 189 &, 050 &, 713 \\
kp5 & 32,48 & 2,763 &, 205 &, 081 &, 716 \\
kp6 & 32,25 & 2,616 &, 352 &, 147 &, 682 \\
kp7 & 32,44 & 2,483 &, 570 &, 604 &, 638 \\
kp8 & 32,43 & 2,610 &, 649 &, 687 &, 639 \\
kp9 & 32,43 & 2,737 &, 412 &, 231 &, 671 \\
\hline
\end{tabular}

. Source : Output SPSS, 2018

By using the number of respondents 95 people, the r-table value can be obtained through $\mathrm{df}$ $($ degree of freedom $)=\mathrm{n}-2$. So $\mathrm{df}=95-2=93$, then $\mathrm{r}$-table $=0.1698$. The question item is said to be valid if the value of $r$-count is the value of the corrected Item-Total Correlation where the calculated $r$ value is more smaller than the $r$ table.

Table 3. Employee Reliability Test Results

\begin{tabular}{|r|c|c|}
\hline $\begin{array}{c}\text { Cronbach's } \\
\text { Alpha }\end{array}$ & $\begin{array}{c}\text { Cronbach's Alpha Based on } \\
\text { Standardized Items }\end{array}$ & N of Items \\
\hline, 704 &, 712 & \\
\hline
\end{tabular}

A construct or variable is said to be reliable if the value of Cronbacch Alpha $(\alpha)>0.60$. Whereas in the SPSS 20 test, for the variable reliability test, it was known that the reliability value of Cronbach's Alpha was 0.704> 0.60. This proves that the questionnaire instrument in the study is reliable and researchable. 
Table 4. Employee Validity Test Results Item-Total Statistics

\begin{tabular}{|l|r|r|r|r|r|}
\hline & Scale Mean if & \multicolumn{1}{c|}{$\begin{array}{c}\text { Scale } \\
\text { Variance if } \\
\text { Item Deleted }\end{array}$} & $\begin{array}{c}\text { Corrected } \\
\text { Item-Total } \\
\text { Correlation }\end{array}$ & $\begin{array}{c}\text { Squared } \\
\text { Multiple } \\
\text { Correlation }\end{array}$ & $\begin{array}{c}\text { Cronbach's } \\
\text { Alpha if Item } \\
\text { Deleted }\end{array}$ \\
\hline kk1 & 25,97 & 4,676 &, 390 &, 276 &, 680 \\
kk2 & 25,66 & 4,350 &, 449 &, 291 &, 664 \\
kk3 & 25,69 & 4,516 &, 317 &, 242 &, 695 \\
kk4 & 25,80 & 3,988 &, 410 &, 250 &, 676 \\
kk6 & 25,54 & 4,138 &, 379 &, 235 &, 683 \\
kk7 & & & & \\
\hline
\end{tabular}

By using the number of respondents 35 people, the value of r-table can be obtained through $\mathrm{df}$ $($ degree of freedom $)=\mathrm{n}-2$. So $\mathrm{df}=35-2=33$, then $\mathrm{r}$-table $=0.2826$. The question item is said to be valid if the count value is the value of the corrected Item-Total Correlation where the calculated $\mathrm{r}$ value is smaller than the $\mathrm{r}$ table.

1) Financial Perspective

a) Return On Assets (ROA)

\begin{tabular}{|l|c|c|}
\hline & $\mathbf{2 0 1 3}$ & $\mathbf{2 0 1 4}$ \\
\hline Earning & 1.148 .613 .384 & 1.433 .488 .975 \\
\hline Total Assets & 14.333 .887 .800 & 16.883 .555 .355 \\
\hline ROA ( \% ) & $8,01 \%$ & $8,49 \%$ \\
\hline
\end{tabular}

Source: Financial Report of PT. BPR Sinar Wuluhan Artha (data processed)

The value of Return On Assets (ROA) generated by the company has increased, which indicates that the ability of PT. BPR Sinar Wuluhan Artha in utilizing its assets to obtain net profit is not good, so the score obtained by PT. BPR Sinar Wuluhan Artha is $0.3 \%$ or it can be categorized as having poor performance.

b) Return On Equity (ROE) 


\begin{tabular}{|l|c|c|}
\hline & $\mathbf{2 0 1 3}$ & $\mathbf{2 0 1 4}$ \\
\hline Earning & 1.148 .613 .384 & 1.433 .488 .975 \\
\hline Capital & 2.481 .208 .870 & 2.877 .166 .461 \\
\hline ROE ( \% ) & $46,29 \%$ & $49,82 \%$ \\
\hline
\end{tabular}

Source: Financial Report of PT. BPR Sinar Wuluhan Artha (data processed)

Based on the measurement results, the results show that the return on equity (ROE) in the company has increased from 2013 to 2014 where the company has been able to increase the percentage of ROE, but has not been able to make a maximum return on shareholder capital (equity) invested in the company., then the score obtained by PT. BPR Sinar Wuluhan Artha is $10 \%$ or this company is in the medium category or between quite good and good.

c) Net Profit Margin (NPM)

\begin{tabular}{|l|c|c|}
\hline & $\mathbf{2 0 1 3}$ & $\mathbf{2 0 1 4}$ \\
\hline Earning & 1.148 .613 .384 & 1.433 .488 .975 \\
\hline Sale & 4.211 .476 .651 & 5.192 .106 .917 \\
\hline ROA (\%) & $27,27 \%$ & $27,61 \%$ \\
\hline
\end{tabular}

Source: Financial Report of PT. BPR Sinar Wuluhan Artha (data processed)

The Net Profit Margin (NPM) value at PT. BPR Sinar Wuluhan Artha has increased from 2013 to 2014, which shows that the company is able to increase sales of the services it provides. Then the score obtained is $0.6 \%$ or in the category of poor company performance.

2) Customer Perspective

a) Customer Retention

\begin{tabular}{|c|c|c|c|}
\hline Year & Customers who quit & $\begin{array}{c}\text { Total customers } \\
\text { until the end }\end{array}$ & $\begin{array}{c}\text { Level } \\
\text { Retention }\end{array}$ \\
\hline 2013 & 138 & 925 & $14,92 \%$ \\
\hline 2014 & 198 & 1317 & $15,03 \%$ \\
\hline
\end{tabular}

Source: Financial Report of PT. BPR Sinar Wuluhan Artha (data processed)

Customer Retention Level at PT. BPR Sinar Wuluhan Artha shows that customers who do not return have increased. This resulted in customer turnover in 2014 increasing by $0.73 \%$, which means the company is unable to maintain its ability to retain existing customers. So that the score obtained is $2.0 \%$ or in the very good category.

b) Customer Acquisition 


\begin{tabular}{|l|c|c|c|}
\hline Year & Customers who quit & $\begin{array}{c}\text { Total customers } \\
\text { until the end of } \\
\text { year }\end{array}$ & $\begin{array}{c}\text { Level } \\
\text { Retention }\end{array}$ \\
\hline 2013 & 192 & 925 & $20,75 \%$ \\
\hline 2014 & 287 & 1317 & $21,79 \%$ \\
\hline
\end{tabular}

Source: Financial Report of PT. BPR Sinar Wuluhan Artha (data processed)

The value of the customer acquisition rate shows that the total acquititions from 2013 to 2014 increased by $1.04 \%$. So the performance score obtained is $2.0 \%$ or included in the medium category, namely between good enough and not good enough.

b)

Customer Satisfaction

\begin{tabular}{|c|l|c|c|c|}
\hline No. & \multicolumn{1}{|c|}{ Answer } & Score & Ammount & Prosentase \\
\hline 1 & & & & \\
\hline 2 & Nery dissatisfied & 1 & 0 & $0 \%$ \\
\hline 3 & Not satisfied & 2 & 0 & $0 \%$ \\
\hline 4 & Satisfied & 3 & 39 & $4,77 \%$ \\
\hline 5 & Very satisfied & 4 & 704 & $86,17 \%$ \\
\hline Total & & & $\mathbf{8 1 7}$ & $\mathbf{1 0 0 \%}$ \\
\hline
\end{tabular}

Based on the data above, services at PT. BPR Sinar Wuluhan Artha can be said to have provided good service to its customers

The following are the results of data analysis for the four perspectives in the Balanced Score card on performance at PT. BPR Sinar Wuluhan Artha.

Total Score Performance Level PT. BPR Sinar Wuluhan Artha

\begin{tabular}{|c|c|c|c|}
\hline No. & Aspek Yang Diukur & Skor Yang & Skor \\
& & Diperoleh (\%) & Maksimal (\%) \\
\hline
\end{tabular}




\begin{tabular}{|c|c|c|c|c|c|}
\hline 1 & $\begin{array}{l}\text { Perspektif Keuangan } \\
\text { a. Return On Equity ( ROE ) } \\
\text { b. Retuen On Assets ( ROA ) } \\
\text { c. Net Profit Margin ( NPM ) }\end{array}$ & $\begin{array}{c}10 \\
0,3 \\
0,6\end{array}$ & 10,9 & $\begin{array}{l}20 \\
20 \\
20\end{array}$ & 60 \\
\hline 2 & $\begin{array}{l}\text { Perspektif Nasabah a. } \\
\text { Retensi Nasabah b. Akuisisi } \\
\text { Nasabah } \\
\text { c. Kepuasan Nasabah }\end{array}$ & $\begin{array}{l}2,0 \\
2,0 \\
4,0\end{array}$ & 8,0 & $\begin{array}{l}2,0 \\
4,0 \\
4,0\end{array}$ & 10 \\
\hline 3 & $\begin{array}{l}\text { Perspektif Proses Bisnis } \\
\text { Internal } \\
\text { a. Proses Inovasi } \\
\text { b. Proses Operasi }\end{array}$ & 5,0 & 8,0 & 5,0 & 10 \\
\hline 4 & $\begin{array}{l}\text { Perspektif Pembelajaran dan } \\
\text { Pertumbuhan } \\
\text { a. Produktifitas Karyawan } \\
\text { b. Retensi Karyawan } \\
\text { c. Kepuasan Karyawan }\end{array}$ & $\begin{array}{l}3,5 \\
3,5\end{array}$ & 18,5 & $\begin{array}{l}3,5 \\
3,5\end{array}$ & 20 \\
\hline & Total & & $6,9 \%$ & & $0 \%$ \\
\hline
\end{tabular}

Source: Processed Data

The total score of the performance level at PT. BPR Sinar Wuluhan Artha from four perspectives of the Balanced Scorecard is $46.9 \%$, it can be seen that the performance that has been done by PT. BPR Sinar Wuluhan Artha is quite good, this is based on the standards that have been done by previous researchers, namely Vidia Valva in a thesis entitled "Performance Measurement of PT Angkasa Pura I Branch of Hasanuddin Airport Makassar with a Balanced Scorecard Approach", in Sri Maulana Muhammad (2011) the standards used are as follows:

$\begin{array}{ll}\text { Very Good } & : 80-100 \% \text { of the standards } \\ \text { Good } & : 60-80 \% \text { of the standards } \\ \text { Cukup } & : 40-60 \% \text { of the standards } \\ \text { Less } & : 20-40 \% \text { of the standards } \\ \text { Not Good } & : 0-20 \% \text { of the standards }\end{array}$

\section{DISCUSSION}

1) Financial Perspective 
ROE analysis in 2014 has increased, this is due to an increase in profits generated by PT. BPPR Sinar Wuluhan Artha. The ROA value in this company can be further enhanced by increasing profitability by increasing sales of existing services / products at the company and streamlining operating costs. The higher the ROA value, the higher the return or income the company gets. Net Profit Margin analysis that has been done needs to be increased again by the company by increasing net income and sales of existing products or services at PT. BPR Sinar Wuluhan Artha. The bigger or higher the Net Profit Margin, the more efficient the company is in issuing costs related to activities or operational processes, productive and increasing the confidence of investors to invest capital in the company.

2) Customer Perspective

Measurement using indicators of customer retention, customer acquisition and customer satisfaction. This is done to determine customer satisfaction with the services provided by the company and also to determine the company's ability to retain and attract new customers.

3) Internal Business Process Perspective

This perspective consists of the innovation process and the operation process. The innovation process is intended to determine whether the products and services offered are in accordance with what the customer wants, while the operation process is directly related to the sale of services performed by the company.

4) Learning and Growth Perspective

Learning and growth perspectives are measured using indicators consisting of employee productivity, employee retention and employee satisfaction. This indicator is intended to find out how much satisfaction is

perceived by its human resources and the company's concern for its human resources or employees.

\section{CONCLUSION}

Based on the results of data analysis, it can be concluded that, from the financial perspective of PT. BPR Sinar Wuluhan Artha can be categorized as a company that has poor performance. Performance from the customer perspective at PT. BPR Sinar Wuluhan Artha is categorized as a company that has a fairly good performance. The performance of PT. BPR Sinar Wuluhan Artha when measured from the perspective of internal business processes which consists of 2 (two) indicators, namely the innovation process and the operation process can be categorized as a 
company that has a good performance. Performance from a learning and growth perspective at PT. BPR Sinar Wuluhan Artha is categorized as companies that have a very good performance.

\section{IMPLICATIONS}

1) Financial Perspective

The performance of PT. BPR Sinar Wuluhan Artha from a financial perspective is not good, for that we need a business that can improve the company's performance for the better by making operational costs more efficient and offering the latest products or services to increase company sales.

\section{2) Customer Perspective}

The performance of PT. BPR Sinar Wuluhan Artha from the customer perspective is quite good, the company is expected to be better able to retain its customers, attract new customers, provide services that satisfy customers and maintain good relationships with old customers. So that the company's performance when measured using this perspective is better than the previous year.

3) Internal Business Process Perspective

The performance of PT. BPR Sinar Wuluhan Artha from the perspective of internal business processes is good. Companies need to add new innovations to existing products or services in the company according to customer needs and establish appropriate and consistent operating standards.

4) Learning and Growth Perspective

The performance of PT. BPR Sinar Wuluhan Artha from the perspective of learning and growth is very good. To continue to maintain it, companies must always maintain good relationships and communication between superiors and subordinates, improve the health and safety of employees in their work environment, and provide incentives or rewards to employees who excel.

\section{REFERENCES}


ABM : International Journal of Administration, Business and Management, Vol. 1 No. 1 November 2019

Aurora, Novella. 2010. Penerapan Balanced Scorecard Sebagai Tolok Ukur Pengukuran Kinerja ( Studi Kasus Pada RSUD Tugurejo Semarang). Skripsi. Semarang: Fakultas Ekonomi Universitas Diponegoro.

Earl dalam Petrus. 2003. Pengukuran dan Teknik Pengambilan Sampel. Jakarta : Erlangga

Ghozali, Imam. 2005. Aplikasi Analisis Multivariate dengan Program SPSS.Semarang: Badan Penerbit Universitas Diponegoro.

Hansen, Don R. and Maryanne M. Mowen. 2009. Akuntansi Manajerial. Penerjemah : Deny Arnos Kwary. Buku 2, Edisi 8. Jakarta:Salemba Empat.

Kasmir. 2010. Analisis Laporan Keuangan. Jakarta: Rajawali Pers.

Kaplan, Robert. S dan P. Norton. 2000. Balanced Scorecard :Menerapkan Strategi Menjadi Aksi. Terjemahan Peter Yosi Pasladari The Balanced Scorecard : Translating Strategy Into Action. 1996. Erlangga. Jakarta.

Mariana Muhammad, Sri. (2011). Analisis Balanced Scorecard untuk Evaluasi Kinerja Pada PT. PLN (Persero) Makassar. Skirpsi Universitas Hasanuddin.

Mulyadi. 2001. Balanced Scorecard : Alat Manajemen Kontemporer Untuk Pelipatgandaan Kinerja Keuangan Perusahaan. Salemba Empat. Jakarta.

Nugroho, Aditya, Wayan. 2013. Analisis Pengukuran Kinerja Perusahaan dengan Konsep Balance Scorecard (Studi Kasus PT. Wijaya Karya). Skripsi. Universitas Islam Negeri Syarif Hidayatullah Jakarta.

Rangkuti, Freddy.2011: SWOT Balanced Scorecard: Teknik Menyusun Strategi Korporat yang Efektif plus Cara Mengelola Kinerja dan Risiko. Edisi 1, Jakarta : Gramedia Pusaka Utama.

Rumintjap, Lidya, Marisa. 2013. Penerapan Balanced Scorecard Sebagai TolakUkur Pengukuran Kinerja di RSUD Noongan. Jurnal EMBA. Vol.1 No.3 September 2013, Hal. 841-850. Fakultas Ekonomi dan Bisnis Jurusan Akuntansi, Universitas Sam Ratulangi Manado.

Soeratno dan Arsyad, Lincolin, 1988. Metodologi Penelitian Untuk Ekonomi dan Bisnis. Yogyakarta: BPFE.

Sugiyono, 2002. Metode Penelitian Administratif, Edisi Ketiga,. Alfabeta. Bandung. 
Wahyuni, Sri. 2011. Analisis Balanced Scorecard Sebagai Alat Pengukuran Kinerja Pada PT.Semen Bosowa Maros. Skripsi. Fakultas Ekonomi Universitas Hasanuddin Makassar.

Wibawa, Chandra.2008. Analisis Balanced Scorecard Terhadap Kinerja BPRS As Salam. Skripsi. Fakultas Syari'ah dan Hukum Universitas Islam Negeri Syarif Hidayatullah Jakarta.

http://jurnal-balanced-scorecard-sebagai-alat-ukur-kinerja-dan_files (26/08/201517:38 p.m http://www.informasi-pendidikan.com/2013/08/penelitian-deskriptif- kualitatif.html (04/10/2015) 00:01 p.m.

http://www.balancedscorecard.com, ( 03 Pebruari 2016 ) 12.39 a.m. http://rumushitung.com, (25 Mei 2016 ) 06.58 a.m 